\title{
Evaluation of the Quality of Education Services
}

\author{
Yayah Huliatunisa*, Dadang Suhardan, Suparta Rasyid \\ Postgraduate Educational Administration \\ Universitas Pendidikan Indonesia \\ Bandung, Indonesia \\ *yayah.huliatunisa@upi.edu
}

\author{
Irawati Sabban \\ Morotai Pasific University Indonesia \\ North Maluku, Indonesia
}

\begin{abstract}
This study aims to examine the implementation of the quality of education services at the Faculty of Health Sciences, Muhammadiyah University of Tangerang. After several problems were found such as; service procedures are still in a manual pattern, there are mismatches of data between Faculties and Universities, there has been no development for improving the skills of education personnel, leaders who rarely attend so that have an impact on obstruction of communication and decision making, and inadequate infrastructure. The data was reviewed through the evaluation component CIPP (Context, Input, Process, Product) and compared to 8 National Education Standard and Guidelines for the Quality Assurance System of the Muhammadiyah University of Tangerang. It was also assessed using five TERRA service quality indicators, including: (Tangibility, Empathy, Reliability, Responsiveness, Assurance). This study was performed using a qualitative approach with descriptive, evaluative, and cross-sectional case studies through interviews, observation, and document study. The results demonstrated the poor implementation of quality education services. This was reviewed through evaluation components: 1 . Context (Quality standards of the Faculty of Health Sciences, Vision, Mission, Values and Goals, Development Plan) based on indicators (Tangibility, Empathy); 2. Input (students, teaching staff and education, financing, infrastructure) based on indicators (Tangibility, Empathy); 3. Process (decision making, learning activities) based on indicators (Responsiveness, Reliability); 4. Product (academic-performance, non-academic), based on indicators (Assurance).
\end{abstract}

Keywords-evaluation, quality education services, quality of TERRA services

\section{INTRODUCTION}

To provide the professional graduates in the health sector and maintain the Faculty of Health Sciences as the favourite institution in Tangerang, the Faculty of Health Sciences of Muhammadiyah, as part of the Muhammadiyah Higher Education organized Higher Education in the health sector. Initially, it was named Muhammadiyah College of Health Sciences in 2002 and becoming the Faculty of Health Sciences, the Muhammadiyah University of Tangerang, in 2009. Nonetheless, various issues such as the inadequate development and training process for resources skills (especially for non-lecturer academic staff), the institution encounters several obstacles such as mismatch of data between Faculties and Universities and inadequate facilities and infrastructure. The decision-making process is also centralized by one of the leaders because of the frequent absence of other leaders. It might because the work at the Faculty of Health Sciences, the University of Muhammadiyah Tangerang, is the stakeholder's secondary job.

The Faculty of Health Sciences, University of Muhammadiyah Tangerang keep striving to improve in the better curriculum and learning process, better quality teaching staff as well as facilities and infrastructure, and better educational management. In addition, public demand for adequate educational services is also increasing. It encourages the Faculty of Health Sciences, Muhammadiyah University of Tangerang to provide the best service to keep presence in the increasingly fierce competition condition. Furthermore, customer expectations continue to grow along with the more information that is received easily and quickly. The development of the customer experience also might affect the perceived satisfaction by customers. The quality of educational services sometimes can unwittingly turn into less quality due to several factors such as lack of skill development (training, coaching) or lack of encouragement to have higher education for academic staff, especially in the financial, academic, and general administration sector which mainly support staff in providing service process at a university.

Some of these obstacles may occur in other institutions because of inappropriate educational services. Besides, the rapid development of science and technology impacts the increasing demands of social life as customers of education. Therefore, academic needs are believed and hoped to answer, overcome, and anticipate various life challenges and provide a better future experience.

Students are educational customers, and the service should satisfy them as well as the community/parents.

Education is always required to continue to make changes and improvements in its management. The quality of education is closely related to the educational process because it is impossible to obtain quality service products without a quality education service process. In other words, there will be no satisfaction with the service provided. 
More recent studies of service quality in education were focused on higher education as more universities and colleges clamour and compete to gain some ranking and accreditation in their programs and institution. Hence, in the quest for internationalization of quality in education, assurance of service quality takes centre stage. Service quality enhances a university's image [1].

The high level of competition among private colleges that offer similar courses has not made it any easier. For example, a private college here offers niche safety courses for diploma students faces four competitors that also offer the same courses. Hence, delivering quality service has become an important goal for most HEIs and to distinguish it among other common competitors [2]. Both the interpretation and the evaluation of $\mathrm{HE}$ quality is quite complex since the different stake- holders addressed to the aforementioned operational levels of HE are increasingly aware and conscious when setting expectations towards institutions (HEIs) and when evaluating the perceived performance and quality [3]. This degree of complexity is also formed by the special characteristics of HE services and the lack of agreement of the customer concept [4].

Quality must always be the primary concern. The quality does not occur due to coincidences but must go through a planned process, which is called the concept of quality. Thus, to achieve a high quality of education, goals must be formulated, policies must be made and defined, facilities must be provided, and every task implementation must be coordinated. These activities will eventually depend on the number of people (in this case, education staff). Therefore, the education staff must be specially prepared, educated, skilled, and selected. Managing the academic staff is about developing human resources in an educational institution and an integrated action and the value of planning, developing, coaching, assessing, and others. In other words, these actions are integrated, continuous, and are interrelated with each other. In the end, it will directly contribute and have a real impact on the quality of education services. The quality services depend on various aspects, including the pattern of implementation (governance), human resource support, institutions, and a clear concept.

The focus of evaluation on the implementation of the Quality of Education Services at the Faculty of Health Sciences, Muhammadiyah University of Tangerang was reviewed through the evaluation component:

- Context

- Service quality standard

- Vision, mission, value, and goal

- Development plan

- Input

○ University student

- Educator and academic staff

- Education financing

- Educational facilities

- Process

○ Decision making

- Learning activities

- Product

- Academic achievement

\section{○ Non-academic achievement}

It was compared to 8 National Education Standards and 16 practice of Guidelines for the Quality Assurance System of the Muhammadiyah University of Tangerang, using five indicators assessment of TERRA service quality, including: (Tangibility, Empathy, Reliability, Responsiveness, Assurance).

\section{LITERATURE REVIEW}

The education field as a place to develop science must synergize its main points of thought holistically into the strategic quality management to each educational unit, starting from primary, secondary, and higher education. As higher education and centres for developing science and technology, tertiary institutions are expected to increase their role in advancing and accelerating national development through science and technology development. Thus, as stipulated in the National Education System Law, Tertiary Education Institutions are granted independent autonomy [5].

- The implementation of education and development of science in tertiary institutions includes academic freedom, academic sharing freedom, and scientific autonomy.

- Tertiary Education has the autonomy to manage their institutions as centres of higher education, scientific research, and community service.

To develop the quality of human resources, qualified educational institutions are needed. Thus, higher education in its implementation must involve all parties, including parents, society, and the industrial world.

Higher Education is a service institution, and services cannot be physically observed, but services can be felt. A good and professional educational service will answer how far the students/customers can achieve and feel satisfaction.

The words "customer" and "customer satisfaction" are needed when discussing quality to emphasize an institution's service relationship with those who need service. This is a straightforward thing but has a critical consequence for the continuity of an organization [6].

Argued customers in the context of educational services:

"Main customers" are students and other same kinds who directly receive services. 'Second customers' are parents, governors, or student sponsors who have direct individual or institutional interests. The 'third customers' are parties who have an important and albeit indirect roles, such as the government and society as a whole [6].

A service is a transaction between two parties: a service provider and a service user [7]. According to the Indonesian dictionary [8], service is:

- Subject or way of serving.

- Efforts to serve the needs of others by earning a reward (money); services. 
- The convenience provided in connection with the sale and purchase of goods or services.

Quality is a relative concept with many definitions. From the various definitions, "what is called quality is something that is satisfying and can provide excellent service and exceed the customer needs and demands" [9], "in the context of education, the definition of quality includes the input, process, and output of education" [9].

To make a competitive climate in higher education institutions, higher education institutions must have independence, openness, and accountability in its management. Thus, tertiary institutions must have a quality assurance system that is a systematic plan that ensures that what the tertiary institution has planned can be implemented and achieved [10].

Generally, the quality can be defined as the overall description and characteristics of a product related to consumer needs' fitness. The definition of quality in the educational process refers to education and educational outcomes" [11] ... which is focused on the fulfilment of the needs of customers who are the community, [12] "Quality is conformity with market needs, according to Juran quality is compatibility with products.

According to Crosby, interpreting quality following what is required.

The term quality also refers to "all policies, procedures, and activities of higher education". The quality can be defined as adequate facilities, curriculum and completeness, competent teaching staff, good learning processes and evaluation systems, and a conducive college environment [13]. Besides, fostering a quality culture in a higher education institution can meet all interested parties' expectations and satisfaction, including internal and external stakeholders [14]

Tjiptono [15] stated customer satisfaction as "the level of a person's feelings after comparing the performance (or results) he feels to his expectations. Interpreting satisfaction, basically, humans naturally will not feel satisfied, but the efforts to make this happen should be conducted.

Satisfying customer needs means providing service quality to customers. Since the quality equals customer satisfaction, to achieve quality involves the need to do everything well. Higher education must organize services appropriately and proportionally so that quality can be achieved. Quality also means an indicator or a measure for quality. Higher education needs to develop a quality system to prove to customers that they can provide high-quality services.

Customer satisfaction will not be fulfilled if Higher Education cannot empower quality sources through quality dimensions. This must be applied and owned in both scope (inside / outside) together, trying to make it happen.

The dimensions of quality in question are [15]:

- The work dimension of the organization

- Working climate

- Additional value
- Conformity and specifications

- Quality of service and durability resulted from the development of public perception.

- It is required the measurement to maintain standards and processes to keep it within the agreed tolerance limits.

Measurements can be made by using five service rating measures [16] which identify the main dimensions with TERRA service quality (an analysis to measure five dimensions of service quality):

- Tangibles (direct evidence): physical facilities, equipment, personnel, and means of communication.

- Empathy: the ease in making good communication relationships, personal attention to understand the needs of customers.

- Reliability: the ability to provide the service immediately, accurately, satisfactorily, and reliably.

- Responsiveness: the desire of staff to assist customers and provide responsive service.

- Assurance: the knowledge, ability, courtesy, and trustworthiness of staff, free from harm, risk, or doubt.

Customers continue to increase their quality requirements, which in turn increases interest in using Total Quality Management [17].

Seymour [18] suggested colleges and universities adopt a market-driven service quality model to assess student satisfaction with support services. Higher education quality is about efficiency, high standards, excellence, value for money, fitness with the goal and/or customer focus.

Defined the quality of education: 'the knowledgeability of students that meet the stated requirements' - requirements set by employers, accreditation institution, professional societies, etc. However, the university's diverse product/service mix to internal and external 'customers' requires a broader definition $[19,20]$.

Quality systems adapted from business and industrial operations need to be reoriented and re-fitted for higher education context to shift the focus from management-based to educationbased practices. One way is to evaluate the effectiveness of the system through a series of activities based on the concept of educational evaluation. Thus, judgment and decision-making must precede evaluative activities [21].

Teo Boon Chui [2] suggested a mental model for testing quality service by examining the differences between customer expectations and actual quality service perceptions. When expectations are appropriately met, the quality of the service provided will be profitable.

The recent studies of quality in education services were focused on higher education as more and more universities and colleges are demanding and competing for rankings and accreditation in their programs and institutions. Therefore, in efforts to internationalize quality in education, service quality 
assurance has become the centre of attention. Quality of service enhances the image of the university [22].

Stated that 'education is the answer to the 21st Century; It can preserve civilization and demand from a human being with a new mentality or social characters; its new priority status in society is determined by the objective needs of the developing society [23].

In accordance with the UNESCO, Policy Paper for Change and Development in Higher Education, the quality of education is considered in the framework of a multi-purpose conception, embracing all the main functions and types of university activities, which also includes an important element as the ability of graduates to find employment immediately.

Communique of the Conference of Ministers of Education, Petrovskiy [24] stated that the responsibility for the quality of higher education lies with each particular university. For this reason, the national quality assurance system must include:

- Assign the responsibilities of organizations and institutions that take part in the educational process;

- Evaluation for both internal and internal of university programs;

- Accreditation system, certification, and other procedures;

- Evidence of international cooperation evaluation and network programs.

Higher education has all the characteristics of the service industry, and it is Mental Intangible Actions, Stimulus Processing (Services Directed at People's Minds), according to Lovelock [25] the services that touch one's mind and can shape attitudes and influence a person's behaviour. The universities are expected to pay more attention to the assessment of society or industry in the skills and abilities of their graduates and how these students feel about their educational experiences [26].

Program evaluations produce information concerning the design, implementation, and assessment of the results of the efforts that have been made to solve the problems [27].

Program evaluation results can be used as a benchmark to find solutions for the problems, and development can also become the basis in making decisions regarding the program. The training program's evaluation becomes an essential thing because it aims to find information about its success rate. According to Arikunto and Jabar [28], program evaluation is an activity to determine how high the program's success rate is, to find out whether the educational goals have been achieved and the efforts to provide information to be conveyed to the decision-makers.

\section{METHODS}

This research was conducted using a qualitative approach, with a cross-sectional case study method (short research time). It aims to evaluate the implementation of the quality of education services at the Faculty of Health Sciences, Muhammadiyah University of Tangerang. This research was based on eight National educational standards and 16 good practice guidelines of the University of Muhammadiyah Tangerang's quality assurance system. Notably, five indicators of assessment of TERRA service quality were used, namely: 1. Tangibles (physical evidence), 2. Empathy 3. Reliability, 4. Responsiveness, 5. Assurance. The analysis was conducted through the evaluation of the CIPP component in a natural setting. Thus, it was expected to find an understanding of the meaning of inductively.

Mainly, the CIPP evaluation model was based on Daniel Leroy Stufflebeam due to the following reasons:

- The CIPP evaluation model is based on the view that implementing an educational program is supported by various factors, such as student characteristics, environment, program objectives, and equipment used. Procedures and mechanisms for implementing the program itself describe the strengths and weaknesses of the evaluated program.

- The CIPP evaluation model's four words are evaluation targets, which are the activity program's components and processes. In other words, the CIPP evaluation model is an evaluation model that views the program being evaluated as a system.

- The CIPP evaluation model is intended to evaluate the process of specifying, delineating, or defining and explaining, focusing the information needed to obtain and provide useful information for assessing data alternatives or information. Therefore, in the evaluation process, evaluators will help measure and collect the data and quickly analyse the received data.

- Provide a comprehensive study of an observed social phenomenon. Thus, a combination of descriptive qualitative research is expected to produce descriptive conclusions and generate recommendations.

In its implementation process, the CIPP evaluation model divides the behavioural descriptions according to what researchers will observe further. It is based on 8 National Education Standards and 16 Good Practices Quality Assurance System Guidelines, Muhammadiyah University of Tangerang, and assess the indicators for TERRA service quality:

- Tangibles (physical evidence): the availability of physical facilities including complete infrastructure (involves the information technology), human resources (teacher and academic staff), policies, vision, mission, values and goals, and students.

- Empathy: make it easier for designed procedures by paying attention to customers' needs. It includes education funding and development plans.

- Reliability: the ability to provide reliable services related to competencies. It includes learning activities.

- Responsiveness: a strong desire to solve the obstacles by providing services quickly and accurately. It includes the decision-making process.

- Assurance (guarantee): the ability to provide assurance includes knowledge, ability, for the results that have 
been given, including academic achievement and nonacademic achievement.

The implementation of the CIPP evaluation model is described in detail:

- Background of program implementation through the context evaluation component: Guidelines for the Quality Assurance System of the Muhammadiyah University of Tangerang, Vision, Mission, Values, and Goals, and the Development Plan.

- Indicators that become an input to program implementation include the evaluation component of Inputs: Students, educators and academic staff, education financing, and educational infrastructure facilities.

- Implementation of the program follows what has been determined and becomes the provisions and what will happen in its performance. It includes the component evaluation Process: Decision Making and Learning Activities.

- Evaluate whether the results that have been carried out following what is desired. It includes the Product evaluation component: Academic and Non-academic Achievements.

Furthermore, the data/information was compared with eight National Education Standards and 16 Good Practices of the Quality Assurance System Guidelines for the University of Muhammadiyah Tangerang. Furthermore, the five TERRA's service quality assessment indicators were used.

The data was collected through interviews and document study, assisted by several supporting tools such as interview guidelines, document study sheets, and various sources needed. The participant is Vice Deans I and II, Head of Sub-division of General Affairs and Civil Service, Lecturers, and Students.

The data was analysed through qualitative descriptive, which described and interpreted each CIPP component indicator's data. Furthermore, it is evaluated using the Miles and Huberman interactive model.

The measurement criteria that will be carried out on the object of evaluation are show in Table 1:

TABLE I. OBJECT EVALUATION

\begin{tabular}{|l|l|l|l|l|}
\hline No & \multicolumn{1}{|c|}{ Context } & \multicolumn{1}{|c|}{ Input } & \multicolumn{1}{|c|}{ Process } & \multicolumn{1}{|c|}{ Product } \\
\hline 1 & $\begin{array}{l}\text { Guidelines } \\
\text { system }\end{array}$ & $\begin{array}{l}\text { Decision } \\
\text { making }\end{array}$ & $\begin{array}{l}\text { Academic } \\
\text { achievement }\end{array}$ \\
\hline 2 & $\begin{array}{l}\text { Vision, mission, } \\
\text { values, and goals }\end{array}$ & $\begin{array}{l}\text { Educator and } \\
\text { academic } \\
\text { staff }\end{array}$ & $\begin{array}{l}\text { Learning } \\
\text { activities }\end{array}$ & $\begin{array}{l}\text { Non-academic } \\
\text { achievement }\end{array}$ \\
\hline 3 & $\begin{array}{l}\text { Development } \\
\text { plan }\end{array}$ & $\begin{array}{l}\text { Education } \\
\text { finance }\end{array}$ & & \\
\hline 4 & & $\begin{array}{l}\text { Educational } \\
\text { facilities and } \\
\text { infrastructure }\end{array}$ & & \\
\hline
\end{tabular}

Triangulation of data/sources are techniques for checking the validity of the data used. This technique was containing data by utilizing additional data for data checking and comparison.

Triangulation aimed to produce valid and reliable data/information. Therefore, triangulation must be carried out through a systematic process. The data/information from the triangulation was discussed, verified, and communicated with stakeholders to determine the reliability and validity of the findings.

\section{RESULTS AND DISCUSSION}

The Faculty of Health Sciences, the Muhammadiyah University of Tangerang, is part of the Muhammadiyah charity business in education

The institutional management of the Faculty of Health Sciences has been written in the statute of the Muhammadiyah University of Tangerang, which contains the basic ideas of institutional control. It is used as a basic guideline for implementing activities related to academic regulations and operational procedures and articles of association and bylaws.

The strategic plan and operational plan described the main tasks and supporting function that complements each other considering vertical and horizontal working relationships to maintain the coordination and communication between institutions within and outside the organization. The supporting management implementation includes; academics, student affairs, research and community service, facilities and infrastructure, human resources, finance, information systems, and personnel's right placement.

After the data was collected and triangulated, it is evaluated using the CIPP evaluation model. In addition, it was analysed and compared with eight National Education Standards and 16 Good Practices Quality Assurance Guidelines for the University of Muhammadiyah Tangerang and assessed using five assessment indicators for TERRA service quality, including:

\section{A. Context of Education Service Quality}

Assist to make decision choices, determine needs to be achieved, formulate program objectives. It was conducted by collecting and analysing data to determine priorities and goa and analyse particular objects, relationships, and programs strengths and weaknesses.

- The service quality standards of the Faculty of Health Sciences, University of Muhammadiyah Tangerang, refer to the guidelines for the Muhammadiyah University Tangerang quality assurance system.

- Vision, mission, values, and goals: The institution is based on university guidelines. The target distributes an academic manual for new students, recruits new staff and lecturers, and introduces recent student studies (PPSM).

- Short and long-term development plans, funding sources from students which managed fully and collaboratively between the Faculty and the university. 


\section{B. Education Service Quality Input}

Analysing problems related to how the available/owned resources are used, and how strategic alternatives can be made to achieve a plan that has been prepared, including:

- College student

- Educators and academic staff

- Education Financing

- Educational facilities and infrastructure

\section{Education Service Quality Process}

Monitoring how the implementation of interaction is carried out with the components in the existing system, including management functions, administrative efficiency, learning effectiveness with continuous supervision. It was conducted through procedures that can be easily monitored, including decision making and Learning Activities.

\section{Education Service Quality Product}

Measuring the achievement of the goals set for the implementation of the program and serves as a discussion of consideration and accountability in making decisions/policies that will be implemented in the future, including: academic and nonacademic achievements.

\section{CONCLUSION}

After comparing result with 8 National Education Standards and 16 Good Practices in the Quality Assurance System Guidelines of the University of Muhammadiyah Tangerang and assessing using five indicators of assessment of TERRA service quality, the evaluation of the implementation of the quality of education services at the Faculty of Health Sciences, Muhammadiyah University of Tangerang can be concluded as follow:

- Lack of the availability of physical facilities (tangibles) and inadequate to be provided for customers (Empathy), including evaluation components of service quality standards, vision, mission, values and objectives, development plans.

- Lack of quality of human resources (Tangibles) and unable to fulfil customers' needs (Empathy), including evaluation components for student input, educators and education staff, education funding, and infrastructure.

- Lack of desire to help solve the problems (Responsiveness) and the lack of ability to provide reliable services and conformity to its competencies (Reliability), including the evaluation component of the decision-making process and learning activities.

- The absence of the ability to provide assurance (Assurance) includes knowledge, the ability for results that have been given to customers, including components of product evaluation of academic achievement, and non-academic achievement.

\section{IMPLICATION}

This study implies that an increase in the competence of graduates and the number of students will be revealed if educational services are based on indicators of TERRA service quality assessment and follow 8 National Education Standards and Guidelines for the Quality Assurance System of Muhammadiyah University of Tangerang.

\section{RECOMMENDATION}

Based on the result, several recommendations to achieve the quality of education services are presented as follow:

- Developing human resources competence by providing opportunities and facilitating the training and continuing education for supported staff regularly.

- The need to complete the learning facilities and infrastructure, including additional classrooms, practicum/laboratory rooms, and laboratory equipment.

- Make job description guidelines, policies, and authorities for the academic community (leaders/lecturers/staff). Thus, the monitoring and evaluation process can be conducted.

- The need to have an online and integrated service system (e.g., academic, financial, and general). Thus, the service process will be more effective and efficient.

- Update the new student admission process's assessment procedure with timeline and flow that make it easier for prospective students.

- Improve communication patterns in all sections to minimize misunderstandings.

\section{ACKNOWLEDGMENT}

I would like to acknowledge supports that following institutions in making this research. Thank you LPDP (Indonesia Endowment Fund for Education), Ministry of Finance, Republic Indonesia for providing me with the financial support during my study at Universitas Pendidikan Indonesia. And the entire academic community of the Faculty of Health Sciences, Muhammadiyah University of Tangerang, for their good cooperation and support for this research process.

\section{REFERENCES}

[1] V. A. Quintal, D. H. Wong, P. Sultan, and H. Y. Wong, "Service quality in a higher education context: an integrated model," Asia Pacific J. Mark. Logist., 2012.

[2] T. B. Chui and M. S. bin Ahmad, "Evaluation of service quality of private higher education using service improvement matrix," ProcediaSocial Behav. Sci., vol. 224, pp. 132-140, 2016.

[3] I. I. Veršić, "Organisational Decision-Making and Academic Institutions," Zagreb Int. Rev. Econ. Bus., vol. 21, no. 1, pp. 37-46, 2018.

[4] V. Surman and Z. E. Tóth, "Investigating service quality issues in higher educational context," Zagreb Int. Rev. Econ. Bus., vol. 22, no. s2, pp. 11-37, 2019. 
[5] P. R. Indonesia, Undang-undang Republik Indonesia nomor 20 tahun 2003 tentang sistem pendidikan nasional. Departemen Pendidikan Nasional, 2003.

[6] E. Sallis, "Total quality management in education: Manajemen mutu pendidikan," Yogyakarta: IRCiSoD, 2012.

[7] J. Kivistö and E. Pekkola, "Quality in administration of higher education,” Sveriges Univ. högskoleförbund, 2017.

[8] E. Setiawan, "Kamus Besar Bahasa Indonesia (KBBI) Online," KBBI Indones, 2012.

[9] S. L. Prabowo, "Implementasi sistem manajemen mutu ISO 9001: 2008 di perguruan tinggi (guidelines IWA-2).” UIN-Maliki Press, 2009.

[10] S. Murwani, "Evaluasi pendidikan: suatu pengantar, dalam evaluasi pendidikan: konsep dan aplikasi.” Jakarta: Uhamka Press, 2006.

[11] S. Sutikno, Pengelolaan Pendidikan Tinjauan Umum dan Konsep Islami. Bandung: Prospect, 2010.

[12] H. Usman, "Manajemen: teori, praktik, dan riset pendidikan," Jakarta Bumi Aksara, 2006.

[13] M. S. Lisbeth, "Konsep Sistem Manajemen Mutu dan Faktor-faktor Yang Mempengaruhi Mutu Pendidikan Tinggi," Artik. Magister Manaj. Perguru. Tinggi. Yogyakarta Univ. Gajah Mada, 2011.

[14] S. H. S. Hassan, "Asia Pacific Quality Network Conference \& AGM," Emerg. challenges, Emerg. Pract., 2007.

[15] A. Supriyanto, "Implementasi total quality management dalam sistem manajemen mutu pembelajaran di institusi pendidikan," J. Cakrawala Pendidik., vol. 1, no. 1, 2011.

[16] N. Khikmah, S. Sunandar, and Y. Yuliejantiningsih, "Implementasi Total Quality Management Dalam Peningkatan Mutu Sekolah Di SMA Negeri 1 Slawi Kabupaten Tegal," J. Manaj. Pendidik., vol. 8, no. 1, 2019.
[17] J. R. Evans and W. M. Lindsay, Managing for quality and performance excellence. Cengage Learning, 2013.

[18] D. Seymour, Total Quality Management on Campus: Is it Worth Doing?, no. 86. Jossey-Bass, 1994.

[19] F. Mizikaci, "A systems approach to program evaluation model for quality in higher education," Qual. Assur. Educ., 2006.

[20] S. Sahney, D. K. Banwet, and S. Karunes, "A SERVQUAL and QFD approach to total quality education," Int. J. Product. Perform. Manag., 2004.

[21] H. Tohidi and M. M. Jabbari, "Service quality evaluating models," Procedia-Social Behav. Sci., vol. 31, pp. 861-865, 2012.

[22] A. Shaw, "Education in the 21st Century," Ethos, vol. 17, no. 1, p. 11, 2009.

[23] UNESCO, Policy paper for change and development in higher education. United Nations Educational, Scientific, and Cultural Organization, 1995.

[24] I. V Petrovskiy and E. N. Agapova, "Strategies of Raising the Quality of Higher Education and Attaining Equality of Educational Opportunities.," Int. J. Environ. Sci. Educ., vol. 11, no. 9, pp. 2519-2537, 2016.

[25] C. H. Lovelock and J. Wirtz, "Services marketing: People, technology, strategy," 2004.

[26] F. Abdullah, "Measuring service quality in higher education: HEdPERF versus SERVPERF," Mark. Intell. Plan., 2006.

[27] J. C. McDavid, I. Huse, and L. R. L. Hawthorn, Program evaluation and performance measurement: An introduction to practice. Sage Publications, 2018.

[28] S. Arikunto and C. S. A. Jabar, "Evaluasi program pendidikan pedoman teoritis praktis bagi praktisi Pendidikan," Jakarta Bumi Aksara, 2004. 